\title{
Petrographic evidence of different provenance in two alluvial fan systems (Palaeogene of the northern Tajo Basin, Spain)
}

\author{
JOSÉ ARRIBAS \& M. EUGENIA ARRIBAS \\ Departamento de Petrología y Geoquimica, Universidad Complutense de Madrid, \\ 28040 Madrid, Spain
}

\begin{abstract}
Palaeogene detrital deposits of the northern Tajo Basin are coalescent alluvial fan systems interfingering distally with lacustrine carbonates. Non-carbonate extrabasinal clasts increase to the east while carbonate extrabasinal clasts decrease. Rock fragments increase to the west, while the feldspar/quartz ratio remains constant. Rock fragments define two sedimentary domains: the Iberian, in the east, was derived from Mesozoic rocks of the Iberian Range, and the Central System, to the west, was derived from Cretaceous cover and Palaeozoic metamorphic basement. Evolution of sandstone composition is related to erosion of the source areas and is different in the two domains. The tectonic setting is apparently 'recycled orogen', providing calcareous rock fragments are included in the total lithic clasts.
\end{abstract}

The Tajo Basin is located in central Spain, and was filled during the Tertiary by continental sediments (carbonate, evaporites and terrigenous). This basin is limited at the NW edge by the Central System, and at the NE edge by the Iberian Range. The Central System is a large exposure of Hercynian granites hosted by low to high-rank metamorphic rocks. The Iberian Range is a mountain belt with double vergence and developed from a depositional trough of the aulacogen type filled with Mesozoic deposits within the Iberian plate (Alvaro et al. 1979). Palaeogene deposits appear scattered along the border of the Tajo Basin. The northern Palaeogene outcrops are nearest to the area of interaction between the Iberian Range and the Central System (Fig. 1).

The base of the studied Palaeogene succession is apparently conformable over a Palaeogene evaporite unit, and the top is partially covered and eroded. The lower part of the Palaeogene succession contains a faunal association of macro- and micro-mammals indicating a Headonian age (Arribas et al. 1983). Within the succession two lithological units (Carbonate Unit and Detrital Unit) are differentiated (Arribas 1986) (Fig. 2). The Carbonate Unit, with a thickness between $200 \mathrm{~m}$ and $500 \mathrm{~m}$, was formed in a variety of carbonate facies within a lacustrine-paludal environment. The Detrital Unit, which grades into the Carbonate Unit contains several detrital facies (lobes, channels, sheets and massive lutites) related to prograding alluvial fans (Arribas et al. 1983). The thickness of the Detrital Unit varies between $200 \mathrm{~m}$ and $340 \mathrm{~m}$.
Thus, the Palaeogene succession reflects evolution from a lacustrine carbonate environment (Carbonate Unit) to a prograding alluvial fan environment (Detrital Unit).

The Palaeogene succession is a synorogenic unit, formed during the build-up of the Alpine chains in a compressive phase that formed the mountain belts of the Iberian Range and Central System. The synorogenic nature of the Palaeogene deposits is documented by the prograding alluvial fan system and the occurrence of important progressive unconformities.

The aim of this paper is to document the sandstone composition of the Palaeogene succession, and to analyse the role of Central System and Iberian Range as source areas during Palaeogene sedimentation.

\section{Methods}

Thirty-nine petrographic thin sections from five stratigraphic sections (Beleña de Sorbe, Membrillera, Torremocha de Jadraque, Negredo and Baides) have been analysed (Fig. 1). The selection of these samples has been made from a representative sampling in each stratigraphic section, sampling sandstones corresponding to the grain size interval $3-0 \phi$. In each thin section a modal analysis of 300 points has been made using the petrographic groups defined by Zuffa (1980). Thus, it is possible to treat the data according to both the 'traditional' (or 'Indiana School' in Ingersoll et al. 1984) and Gazzi-Dickinson methods. Thin sections have been stained with sodium cobaltinitrite and alizarin-red-s solutions for feldspar and carbonate identifications, respectively. 


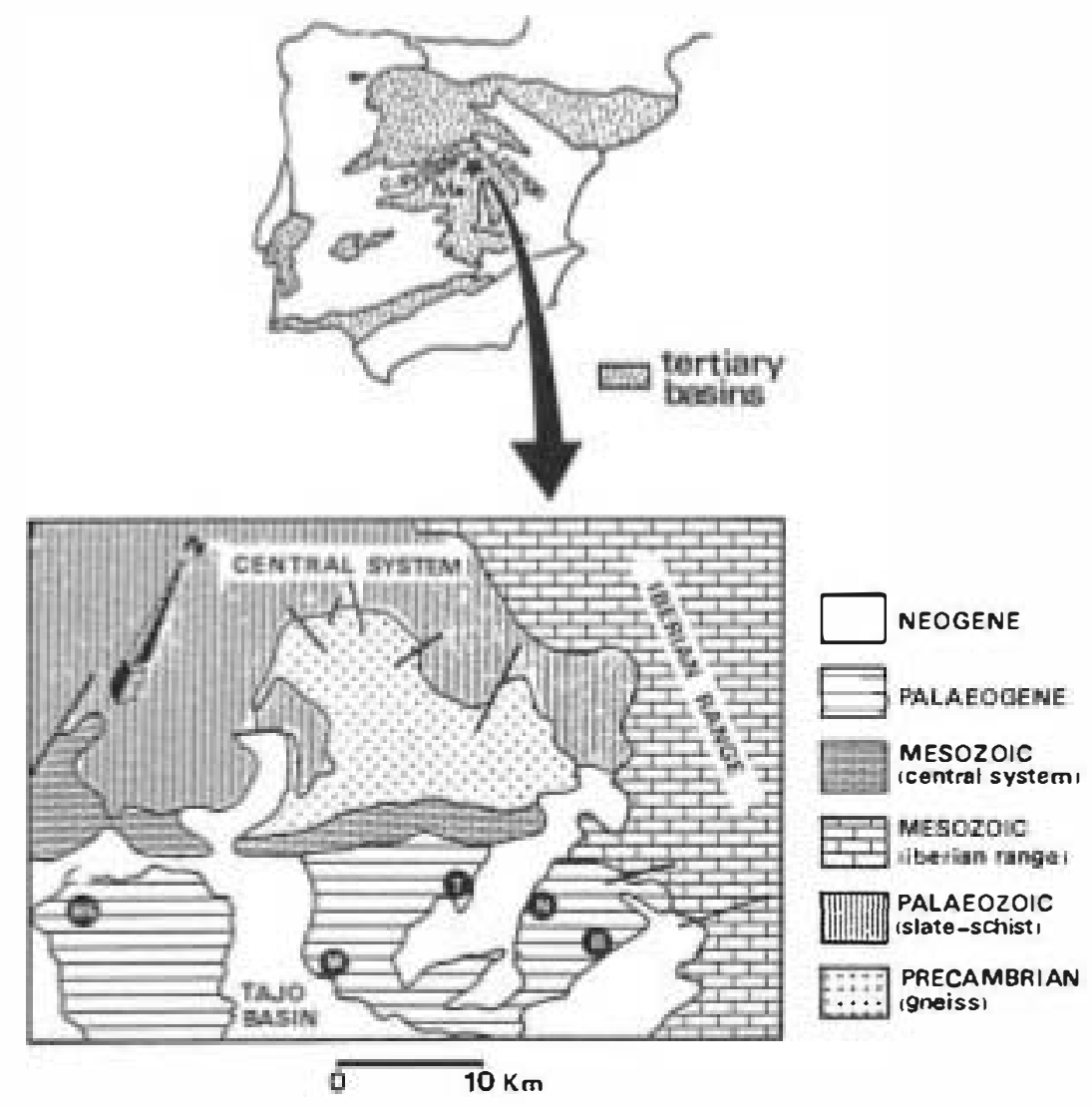

Fig. 1. Geological setting and location map of the stratigraphic sections. BS, Beleña de Sorbe section; M, Membrillera section; T, Torremocha de Jadraque section; N, Negredo section; B, Baides section.

\section{Textures and components of arenites}

Detrital arenites are fine- to very coarse-grained and are well to moderately-well sorted (So = 1.2-2.0). Two main components form the arenite framework: siliciclastic and carbonate grains. Carbonate grains are coarser than siliciclastic particles. Roundness is also controlled by clast compositions; carbonate grains are well rounded (Powers 1953) while quartz grains are subangular-subrounded.

Compaction has produced some pressure solution contacts between clasts of difierent composition (quartz-carbonate grains) and mechanical deformation of labile grains (intraclasts) generating a micritic pseudomatrix.

Generally, the arenite framework is grain supported. However, the tops of some channel-fill sequences are composed of matrix-supported sandstones with high contents of micritic matrix. The origin of this micritic matrix is related to palaeosols and appears to be associated with intrabasinal carbonate grains (pedogenetic intraclasts; Arribas 1986).

The cement is sparry pore-filling calcite with a mosaic texture or as overgrowths around monocrystalline calcite grains.

Sand grains have been divided into the four groups defined by Zufia (1980): (1) non-carbonate extrabasinal (NCE), (2) carbonate extrabasinal (CE), (3) non-carbonate intrabasinal (NCI) and (4) carbonate intrabasinal (CI).

\section{Non-carbonate extrabasinal grains (NCE)}

Four categories have been distinguished: quartz, feldspar, metamorphic rock fragments, and micas and other minerals. Quartz grains are mainly monocrystalline (more than $80 \%$ of total quartz) with non-undulatory extinction. Monocrystalline quartz grains with rounded or irregu- 

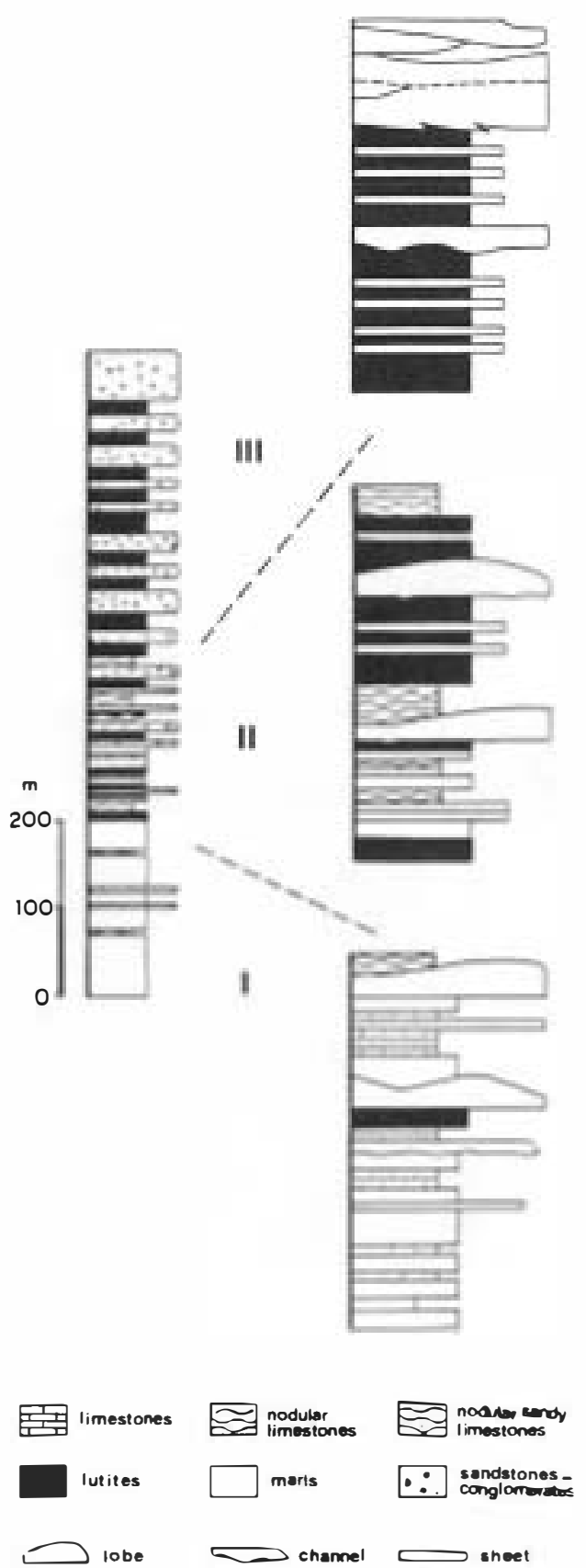

Fig. 2. The representative vertical profile Palaeogene succession. I, the Lower Carbonate Unit (lacustrine sediments); II, the Upper Carbonate Unit (lacustrine, paludal and alluvial fan sediments); III, the Detrital Unit (alluvial fan sediments). lar overgrowths are common, demonstrating a second-cycle origin from previous sandstones. Quartz grains with evaporite mineral inclusions are common. Plagioclase is absent, and $\mathrm{K}$-feldspar occurs as orthoclase and microcline. Some single $\mathrm{K}$-feldspar grains have inherited overgrowths (Fig. 3a). The content of feldspar is low, and never exceeds $15 \%$ of the total framework grains. Metamorphic rock fragments include mica-schist, slate and meta-arkose (Fig. 3b). Phyllosilicates (biotite, muscovite and chlorite) are as accessory components (less than 1\%), and glauconite, phosphate and heavy minerals (tourmaline, zircon and titanite) have also been observed.

\section{Carbonate extrabasinal grains (CE)}

This group is represented by limestone and dolostone fragments. Limestone fragments are generally micritic showing a wide variety of microfacies (mudstones with equinoids, pelmicrites, biosparites, etc.) (Fig. 3c). Dolostone fragments are coarsely crystalline (dolosparites), sometimes partially dedolomitized. Dolomicritic grains are also present but in low percentages (Fig. 3d). Other CE grains include recrystallized bioclasts (mainly molluscs and echinoids).

\section{Non-carbonate intrabasinal grains (NCI)}

These clasts are very scarce and consist of siltyclayey grains, larger in size than associated extrabasinal siliciclastic particles. They are commonly squeezed between other clasts to form pseudomatrix.

\section{Carbonate intrabasinal grains (CI)}

Poorly lithified intraclasts and micritic grains have been distinguished (Fig. 3e). These grains coexist with carbonate extrabasinal grains. The main characteristics used to discriminate between both types of grains have been grain size, roundedness and induration (Zuffa 1980, 1985). Reworked crystal-aggregates of Microcodium have been observed in the sand fraction. Because Microcodium develops in palaeosols, they are interpreted as intrabasinal. Also, some ostracode fragments appear as carbonate intrabasinal clasts (Fig. 3f).

Palaeogene arenites have a variable composition according to the CE-NCE-CI diagram (Zuffa 1980) (Fig. 4). Some have an important CE content, approaching 'calclithite' compo- 

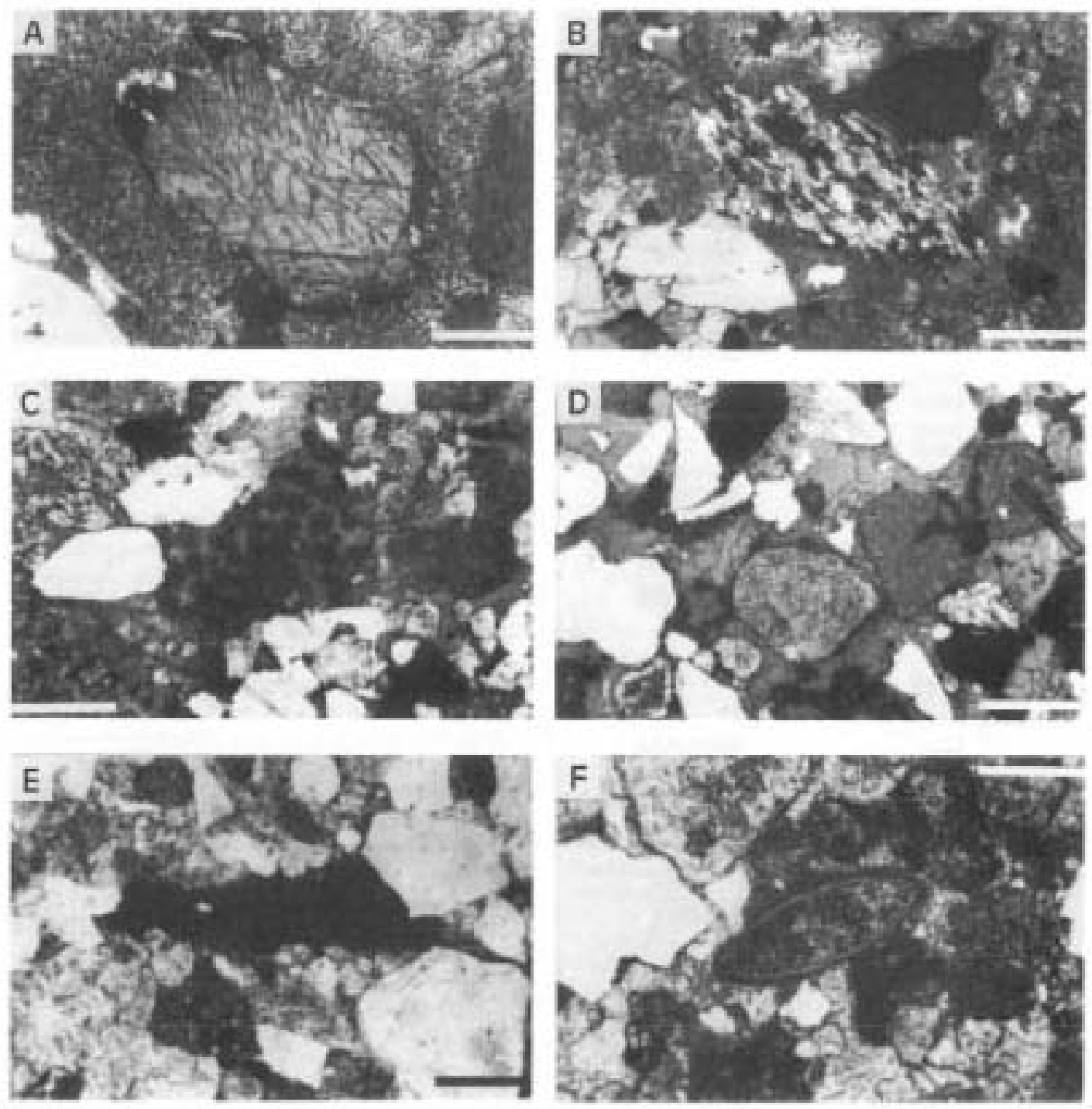

Fig. 3. Detrital components of Palaeogene sandstones. (A) $\mathrm{K}$-feldspar grain with inherited overgrowth Crossed polars. Scale bar, $0.2 \mathrm{~mm}$. (B) Metamorphic rock fragment (mica-schist). Crossed polars. Scale bar, $0.5 \mathrm{~mm}$. (C) Limestone fragment showing a pelloidal microfacies. Crossed polars. Scale bar, $0.5 \mathrm{~mm}$. (D) Extrabasinal dolomitic grains. Plane light. Scale bar, $0.5 \mathrm{~mm}$. (E) Intrabasinal micritic grain showing deformation by mechanical compaction. Plane light. Scale bar, $0.5 \mathrm{~mm}$. (F) Intrabasinal ostracode grain. Plane light. Scale bar, $0.2 \mathrm{~m}$.

sitions (Folk 1959), whereas others are predominantly of NCE type (sandstones sensu stricto.). Finally hybrid arenites are also present, with similar CE and NCE amounts and low percentages of $\mathrm{Cl}$.

According to Pettijohn et al. (1973), the classification of Palaeogene arenites into classic sandstone types is only feasible if only extrabasinal
(CE and NCE) grains are considered (Fig. 5). Thus the terrigenous framework of the Palaeogene arenites is litharenite and sublitharenite. However, this is only valid if all CE grains are plotted at the $\mathrm{R}$ pole on the QFR diagram. Note that some CE grains are monocrystalline or fossil fragments, but are here considered rock fragments. 


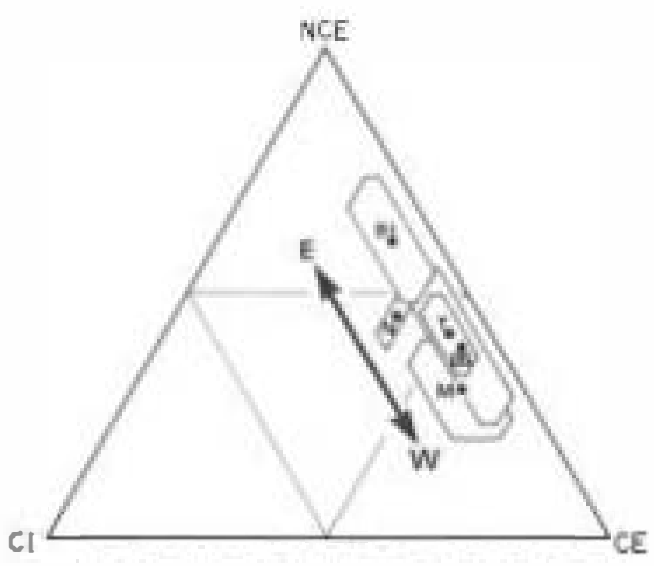

Fig. 4. Ternary plot of mean (point) and standard deviation (hexagons) values of Palaeogene sandstones, according to the criteria of Zuffa (1980). NCE: non-carbonate extrabasinal grains. CE: carbonate extrabasinal grains. $\mathrm{CI}$ : carbonate intrabasinal grains. BS, Beleña de Sorbe section; M, Membrillera section; T, Torremocha de Jadraque section; N, Negredo section; BI, Baides section.

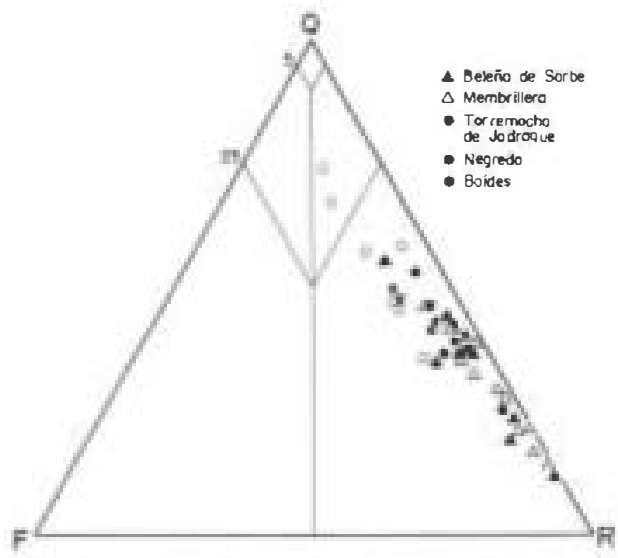

Fig. 5. Composition of terrigenous modes of Palaeogene sandstones in a QFR diagram (Pettijohn et al. 1973). Q, quartz grains; F, feldspar grains; $R$, rock fragments.

\section{Provenance results}

Petrographic parameters indicate that the Palaeogene sandstones are mainly sedimentoclastic (Ingersoll 1983). Most of the lithic fragments are sedimentary (carbonates) (Fig. 6); the presence of abraded quartz and feldspar overgrowths indicates they are second-cycle. However, a small proportion of metamorphic rock fragments is also present, implying input of grains from epicrustal rocks. Sandstone composition varies laterally between different areas, as well as changing through time (upsection), in each area.

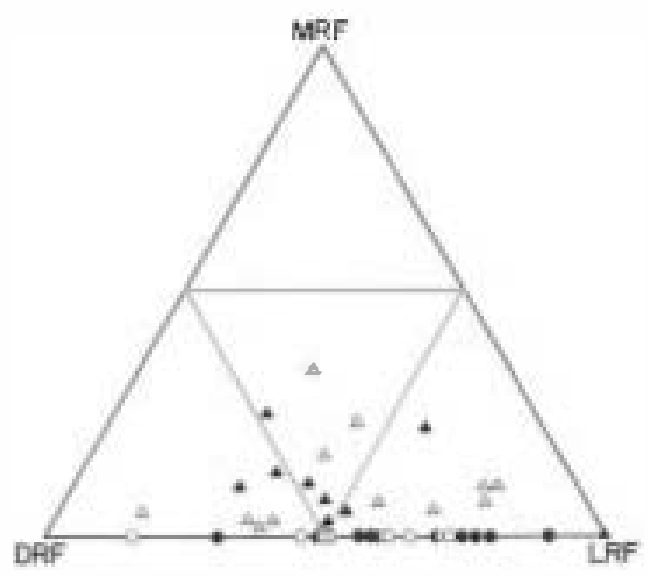

Fig. 6. Composition of total rock fragments in the Palaeogene sandstones. MRF, metamorphic rock fragments; DRF, dolostone rock fragments; LRF, limestone rock fragments. Legend as for Fig. 5.

\section{Sandstone compositon and geographic distribution}

The NCE-CE-CI diagram (Fig. 4) displays a diminution of NCE grains (siliciclastic) from east to west. This relates to the lithology of the source areas. The eastern Iberian Range has a greater potential to produce siliciclastic deposits from Permo-Triassic and Cretaceous sandstone formations compared with the western Cretaceous Central System cover. CI contents are similar in all studied areas, and are associated with cannibalistic erosion of interbedded paludal-lacustrine deposits.

Differences

also be observed on the QFR diagram (Fig. 5). The Palaeogene sandstones from the west (Beleña de Sorbe and Membrillera sections) are rich in rock fragments $\left(Q_{25}-F_{5}-R_{70}\right)$, evolving to $\mathrm{Q}_{40}-\mathrm{F}_{10}-\mathrm{R}_{50}$ (Torremocha de Jadraque and Negredo) and to $Q_{60}-F_{15}-R_{25}$ (Baides) toward the east. Thus, the Iberian Range extrabasinal contribution was mainly quartz and feldspar, while Central System provided more rock fragments. The $\mathrm{Q} / \mathrm{F}$ ratio is very similar in all sandstones, and can be defined as a linear equation: $Q=5 F+9$. This demonstrates that the quartz and the feldspar source must be similar. Siliciclastic Cretaceous formations (e.g. Arenas de 


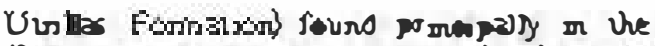

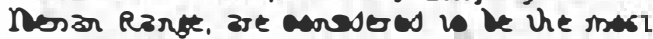
polale soure of quilz alo sedspar.

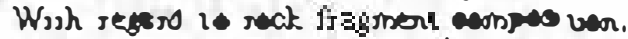

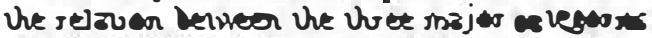

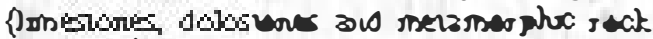

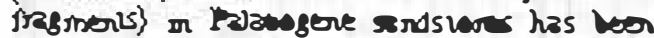

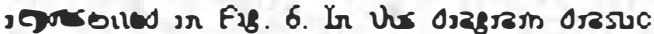

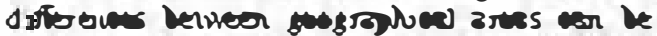

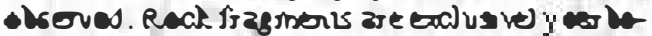

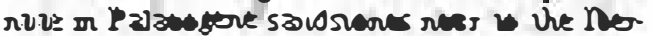

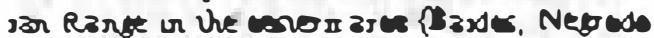

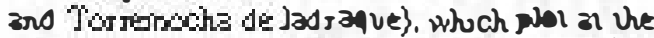

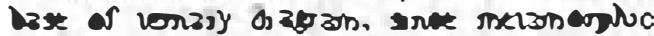

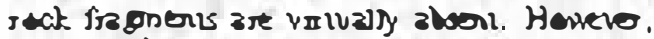

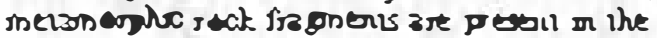

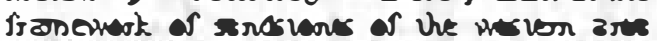

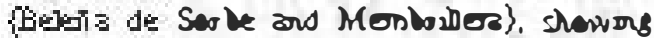

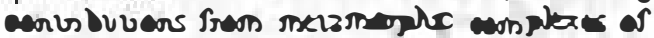

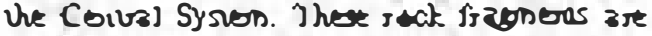

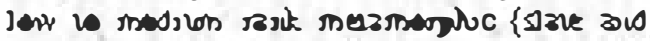
show schsi\}, and $5 \cos$ up is $35 \%$ of the wiz] s ack fs ag sherr.

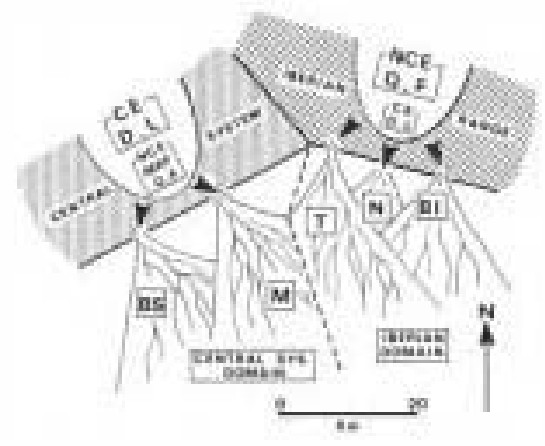

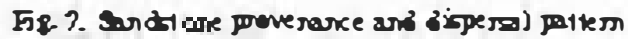

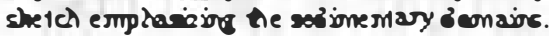

These rolis have onjorarl overer

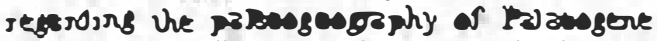

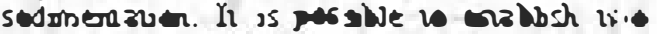

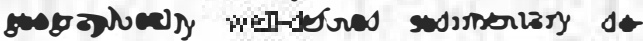

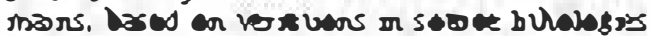
\{F,8. 7): Uhe nesol 0conor in uhe essi pade.

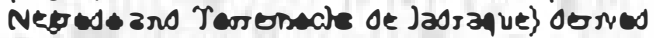

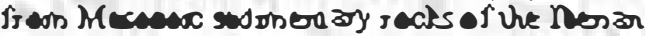

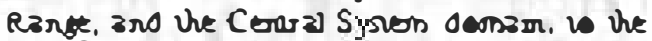

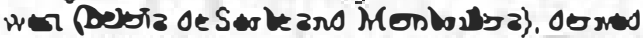

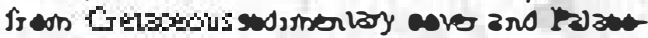

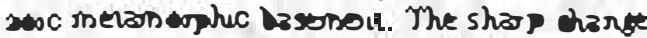
ir MRF corleri \{zlotil of preserly of fizsteweok seroseones shaws the ches bundesy verweor the ocorisis.

\section{Evedurion of sendstere combasition}

Veruç trinds un sandsone coinposulon have beer delerinmed for all five stalgapho secuors, usmg severs] coingosucral mdxes $\{$ Fig. $\mathrm{g}\}$.

NCEINCE + CE VEJUE uncresse up-secuon

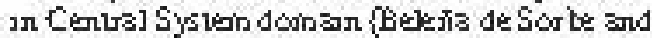

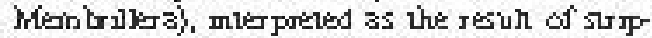
pung off Gelaceous carbonale cover and pogressive uruoofing of the underlyng inelisina phoc canplex. However, thus mdex decreses on Iberis doinam secuors. The upper Mesoboco sucoesson un the lveran Range is 3 thuck (c. 300 in) secuon of Jurzssc carbonale deposis \{dolosiones and hinetones al the $l_{\mathrm{p}}$ \} and 3 Crelareous shockssc forinzucr wh 3 dobinste uru z bove. This, the deoresse of the NCE NCE + CE undex m Iberan Doinan can be refsied to luthologxs] properbes of eroded source rocks, $\approx$ зл 'rivered' suaugropphy of upper Mesolonc sucoesson. These dufter enoes un the evoluuon of ssndsone ocoinposuon verly the exsuenoe of prenously defired sedrineristy doinsius.

Vie uos urends of D/D $+\mathrm{L}$ \{dologone fisginenus vesus wis] carbonale fräginenu\} à simatar 10 those of NCEINCE + CE. The upisid deresse of dobolone fisginerus u ssudsones of the lienan doinsin I becsuse the wp of the hesoocos secuon ur the lbenzr Range I doinmzinly dolcoinuc. Thus, an 'srivered' srugrspho buhobgy of rock frzginert vites

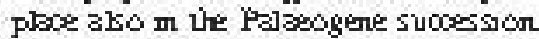

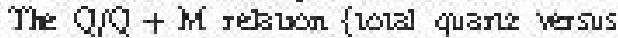

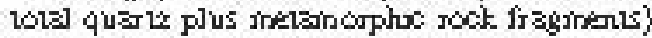

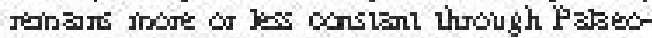

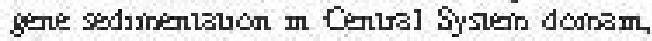
Wheress thus mdex rinsas al j m the lbenzin doinar becsuse $\Delta^{*}$ the sbernoe of ineasinor phuc rock fispinerus.

As drcussed prenouly, 3 dose rebbon

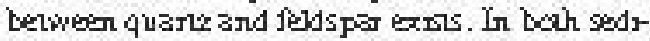
jก: slarl through wire, never exosedung 03. How

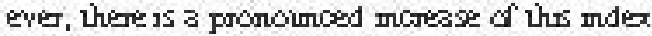
ur the Beleils de Sorbe secuon, unducsung a locs] cortubuuor fioin crysillme rocks. Crenss. roots are exposed un the bover parl of the inelzinorpho coingles of the Cenus] Systein [Soers 1972\} \{fig. 1). Thus, the yourgen Pzlsogere sandsones un the Cerus] Sysuen doinan zлe probsbly rested wo the exposure of grexs roots m the souros 3 res.

\section{Gerrectenic serring and composition}

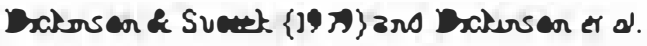



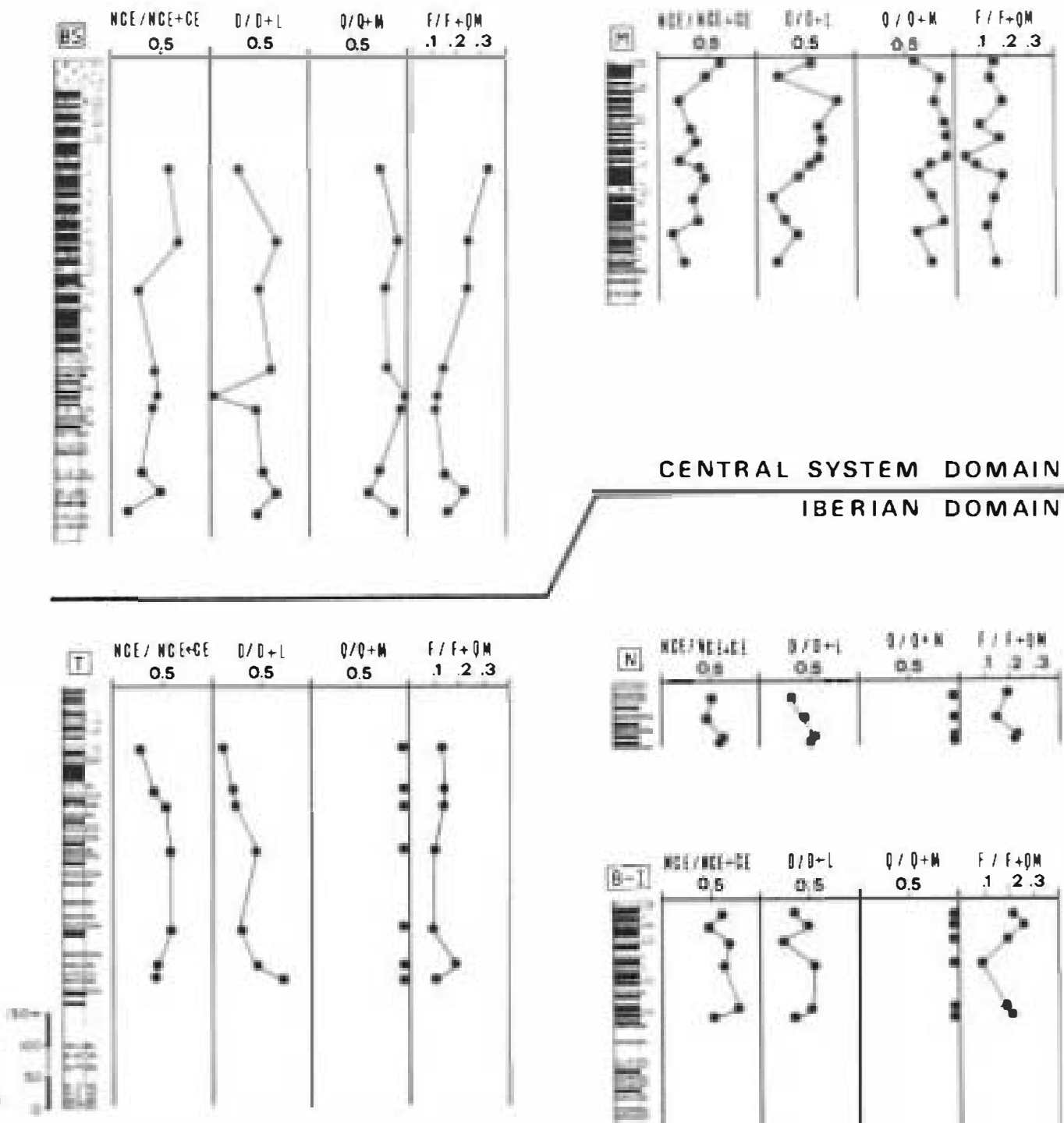

CENTRAL SYSTEM DOMAIN

IBERIAN DOMAIN
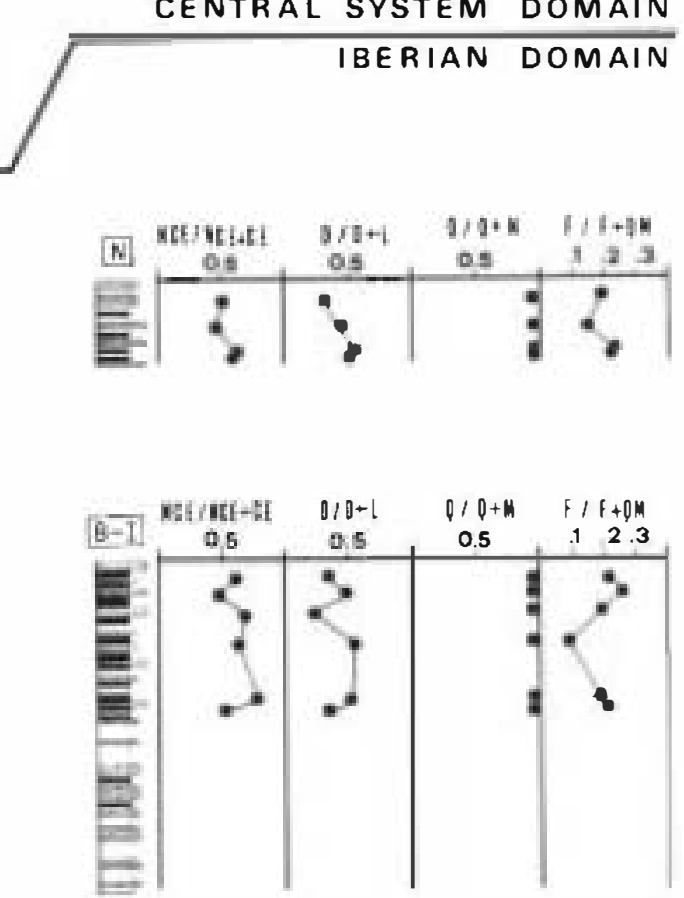

Fig. 8. Vertical trends in sandstone composition of the Palaeogene sections using several indices. BS, Beleña de Sorbe section; M, Membrillera section; T, Torremocha de Jadraque section; N, Negredo section; BI, Baides section.

(1983) pointed out that modal compositions of sandstone suites from specific geotectonic settings plot on QFL and QmFLt ternary diagrams. However, these authors exclude extrabasinal detrital carbonates in calculations of detrital modes. Later, Mack (1984), Zufia (1980) and Ingersoll et al. (1987) have outlined the importance of including such detrital grains in the $\mathrm{L}$ pole.
When plotted on a QFLt diagram, according to Dickinson et al. (1983) criteria (carbonate extrabasinal excluded), all Palaeogene sandstones group together in a problematic area of imprecise provenance (Fig. 9a), within the recycled orogen, stable craton, and 'mixed' provenance fields. However, if carbonate extrabasinal grains (Lc) are included with total lithics (Fig. 9b), all studied Palaeogene sandstones plot 


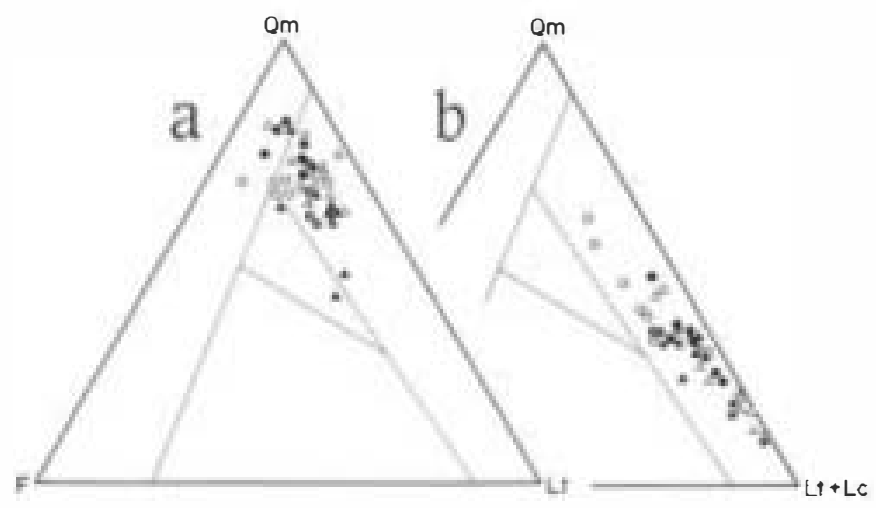

Fig. 9. Composition of Palaeogene sandstones. (a) Following criteria of Dickinson et al. (1983). (b) Including carbonate rock fragments (LC) in lithic pole.

within the recycled orogen provenance field. This inferred provenance is consistent with the regional geological setting. Palaeogene sandstones are syntectonic deposits produced by erosion of the Iberian Range sedimentary succession in the east, and sedimentary (Cretaceous cover) and low to medium rank metamorphic rocks of the Central System in the west, during Alpine tectogenesis.

Furthermore, this distribution of data on the $\mathrm{QmF}(\mathrm{Lt}+\mathrm{Lc})$ diagram is similar to that of the QFR diagram, showing the same geographical distribution of sandstone composition, more lithic in the west.

\section{Conclusions}

Petrographic data on composition of Palaeogene sandstones framework in the northern Tajo Basin suggest that these sandstones are mainly sedimentoclastics (sensu Ingersoll 1983), with a litharenitic composition.

Sandstone composition changes with geographical distribution, with a progressive diminution of NCE grains from east to west. Rock fragments, mainly dolostone and limestone fragments (CE grains), increase to the west. Q/F values remain constant in all localities, indi- cating a common source for these minerals, probably the Cretaceous sandy formations (e.g. Arenas de Utrillas Formation). Carbonate intrabasinal grains $(\mathrm{CI})$ are also present, the result of erosion of contemporaneous lacustrine-paludal deposits.

A detailed analysis of the rock fragments nature permits the establishment of two sedimentary domains: (1) the Iberian domain in the east, derived from Mesozoic sedimentary rocks of the Iberian Range, and (2) the Central System domain in the west derived from Cretaceous cover (sedimentary rocks) and Palaeozoic metamorphic basement of the Central System.

Vertical trends in sandstone composition, on the basis of $\mathrm{NCE} / \mathrm{NCE}+\mathrm{CE}, \mathrm{D} / \mathrm{D}+\mathrm{L}$ and $\mathrm{Q} / \mathrm{Q}+\mathrm{M}$ indices, reveal difierences between both domains, related to the lithological properties of the eroded source terrains.

Finally, we conclude that the sandstone composition is consistent with a recycled orogen provenance (Dickinson et al. 1983). However, this is only clear if carbonate rock fragements (Lc) are included in the total lithic population.

The authors wish to acknowledge R. Valloni and M. A. Velbel for their valuable suggestions. We thank A. Morton for his collaboration in the English version of the text.

\section{References}

Alvaro, M., Capote, R. \& Vegas, R. 1979. Un modelo de evolución geotectónica para la Cadena Celtibérica. Acta Geológica Hispánica, 14, 172 177

Arribas, M. E. 1986. Petrologia y análisis secuencial de los carbonatos lacustres del Paleógeno del sector $\mathrm{N}$ de la Cuenca Terciaria del Tajo. Cuadernos de Geologia Ibérica, 10, 295-334.

- Diaz-Molina, M., Lopez-Martinez, N. \& PorTERO, J. M. 1983. El abanicoaluvial paleógeno de Beleña de Sorbe (Cuenca del Tajo): facies, relaciones espaciales y evolución. $X$ Congreso Nacio- 
nal de Sedimentologia, Menorca, Comunicaciones, 1,3438 .

Dickinsen, W. R. \& Suczek, C. A. 1979. Plate tectonics and sandstone compositions. American Association of Petroleum Geologists Bulletin, 63, 2164-2182.

- \& VAlLONI, R. 1980. Plate settings and provenance of sands in modern ocean basins. Geology, 8, 8286 .

Bear】, L. S., Brakenbrimge, G. R., Erjavec, J. L., Ferguson, R. C., Inman, K. F., Knepr, R. A., Linøberg, F. A. \& RyberG, P. T. 1983. Provenance of North American Phanerozoic sandstones in relation to tectonic setting. Geological Society of America Bulletin, 94, 222235.

Fol K, R. L. 1959. Practical petrographic classification of limestones. American Association of Petroleum Geologists Bulletin, 43, 1-38.

Garzan TI, E. 1986. Source rock versus sedimentary control on the mineralogy of deltaic volcanic arenites (Upper Triassic, northern Italy). Journal of Sedimentary Petrology, 56, 267275.

INGERSOĹL, R. V. 1983. Petrofacies and provenance of late Mesozoic forearc basin, northern and central California. American Association of Petroleum Geologists Bulletin, 67, 1125-1142.

INGersoll, R. V., Bullard, T. F., For》, R. L., Grimm, J. P., Pickle, J. D. \& Sares, S. W. 1984 The effect of grain size on detrital modes: a test of the Gazzi-Dickinson point-counting method. Journal of Sedimentary Petrology, 54, 103116.

- Cavazza, W. \& Graham, S. A. 1987. Provenance of impure calclithites in the Laramide foreland of southwestern Montana. Journal of Sedimentary Petrology, 57, 9951003.

Mack, G. H. 1984. Exceptions to the relationship between plate tectonics and sandstone composition. Journal of Sedimentary Petrology, 54, 212 220.

Pettijohn, F. J., Potter, P. E. and Siever, R. 1973. Sand and Sandstones. Springer-Verlag, Berlin.

Powers, M. C. 1953. A new roundness scale for sedimentary particles. Journal of Sedimentary Petrology, 23, 117119.

SOERS. E. 1972. Stratigraphie et geologie structurale de la partie oriental de la Sierra de Guadarrama. Studia Geologica, 4, 7-94.

Suttner, L. J. \& DutTA, P. K. 1986. Alluvial sandstone composition and paleoclimate, I. Framework mineralogy. Journal of Sedimentary Petro$\log y$, 56, 329-345.

ZufFA, G. G. 1980. Hybrid arenites: their composition and classification. Journal of Sedimentary Petro$\log y$, 50, 21-29.

ZufFA, G. G. 1985. Optical analysis of arenites: influence of methodology on compositional results. In: Zuffa G. G. (ed.) Provenance of Arenites. Reidel, Dordrecht, 165-190. 